\title{
Anatomical features of the syrinx in sea gulls*
}

\author{
Nazan GEZER İNCE ${ }^{1}$, Gülsün PAZVANT ${ }^{1}$, Hasan ALPAK ${ }^{1}$ \\ ${ }^{1}$ Department of Anatomy, Faculty of Veterinary Medicine, University of Istanbul, Istanbul, Turkey.
}

\begin{abstract}
Summary: The syrinx of four sea gulls (Larus spp.) weighing 395-520 g were examined. The syrinx was a tracheobronchial type formed by the bronchosyringeal cartilages (cartilagines bronchosyringeales) and the tracheosyringeal cartilages (cartilagines tracheosyringeales). Five tracheosyringeal cartilages were fused completely and shaped tympanum. Bronchosyringeal cartilages were formed from 7-C shaped cartilage rings. Lateral and medial tympaniform membrane's which are important for vocalization were observed. The lateral tympaniform membrane was observed between $1^{\text {st }}$ and $2^{\text {nd }}$ cartilage rings of bronchosyringeales. Medial tympaniform membrane was placed between the pessulus and $7^{\text {th }}$ bronchosyringeal cartilages. The interbronchial ligament (ligamentum interbronchiale) connects the left and right primary bronchi at the terminal part of the medial tympaniform membrane. Foramen interbronchiale was situated between the medial tympaniform membrane, pessulus and interbronchial ligament. The tracheolateral muscle ( $\mathrm{m}$. tracheolateralis) was attached to the $1^{\text {st }}$ bronchosyringeal cartilages. Similarities and differences of syrinx between sea gulls and other avian species were determined in this study.
\end{abstract}

Key words: Anatomy, aves, sea gull, syrinx, voice

\section{Martı'larda syrinx’in anatomik özellikleri}

Özet: 395-520 gr ağırlıklarında dört adet martının kullanıldığı bu çalışmada syrinx incelendi. Syrinx'in tracheobronchial tip olduğu cartilagines bronchosyringeales ve cartilagines tracheosyringeales'ten oluştuğu belirlendi. Beş adet olan cartilago tracheosyringeales'in kaynaştığı ve tympanum'u şekillendirdiği gözlendi. Cartilago bronchosyringeales'in 7 adet olduğu ve C şeklindeki kıkırdak halkalardan oluştuğu izlendi. Sesin şekillenmesinde büyük role sahip olan membrana tympaniformis lateralis ve medialis görüldü. Membrana tympaniformis lateralis'in 1. ve 2. cartilago bronchosyringealis'ler arasında yer aldığ1 gözlendi. Membrana tympaniformis medialis'in, pessulus ile 7. cartilago bronchosyringealis arasında bulunduğu izlendi. Membrana tympaniformis medialis'in sona erdiği bölgede sağ ve sol bronchus primarius'u birbirine bağlayan ligamentum interbronchiale belirlendi. Membrana tympaniformis medialis, pessulus ve ligamentum interbronchiale arasında foramen interbronchiale'nin yerleştiği izlendi. M. tracheolateralis'in cartilago tracheosyringealis'e bağlandığı belirlendi. Bu çalışmada martı ile diğer kanatlı türlerinin syrinx'leri arasındaki benzerlikler ve farklılıklar ortaya konuldu.

Anahtar sözcükler: Anatomi, kuşlar, martı, ses, syrinx.

\section{Introduction}

Birds are known with their voices, perfect flying capabilities (13) and colors $(4,12)$. Bird vocalization plays an important role on their differentiation. Birds are grouped as passerines and non-passerines according to their voice device's structural differences. Bird vocalizations are seen as singing and calling $(7,12)$. The term 'call' connotes a short, simple vocalization (7). Yelping alarm call, low barking anxiety call and loud laughing calls are the well knowns of the gull's calling.

Passerines have a voice producing organ called syrinx $(4,6,9,11,12,13)$. It is placed at level of the $2^{\text {nd }}$ or $3^{\text {rd }}$ thoracic vertebrae and between trachea and primary bronchus (14). Bottom of the trachea or mostly top of bronchus or both of them participates in the formation of syrinx. It has 3 types according to origination and called tracheal, bronchial and tracheobronchial syrinx $(1,4,5$, $10,11,13,14)$. Tracheobronchial syrinx is consist of tympanum, cartilagines tracheosyringeales and cartilagines bronchosyringeales $(1,10,11,14,15,16,17)$. Two pairs of thin membrane named lateral tympaniform membrane (MTL) and medial tympaniform membrane (MTM) located at syrinx undertake the voice production $(1,3,8$, $10,11,14,15,16,17)$. They are tensed by instrinsic and extrinsic muscles which surrounds syrinx $(15,17)$. Pessulus located vertically at the bifurcation of the trachea splits the airway of the syrinx (1).

Extrinsic muscles consists sternotracheal muscle and tracheolateral muscle $(8,10,13,15,16)$. These muscles have duty of voice production with regulating

\footnotetext{
A part of this study was presented as a poster presentation at $6^{\text {th }}$ National Congress of Veterinary Anatomy, 16-19 September 2010, Afyon-Turkey.
} 
the syringeal aperture (8) and alternating the membrane tension (9).

The aim of this study is to define the anatomic properties of sea gull's syrinx and compared them with other avian species.

\section{Material and Methods}

Four sea gulls (Larus spp.) weighing 395-520 g and living around Istanbul were used. Sea gulls were brought to the Istanbul University Veterinary Faculty Wild Life Research and Protection Club (VAŞAK) to be treated for fractures and other injuries. Four deceased gulls were injected with $5-10$ cc $10 \%$ formaldehyde solution into the thoracic cavity and then submerged and fixed in $10 \%$ formaldehyde solution at least 48 hours.

Using Çalışlar's (2) dissection technique, the thoracic cavity was opened. Syrinx was excised between the terminal part of the trachea and the pulmonary hilus. The syrinx was dissected by removing fat and connective tissue. And then materials were left in $70 \%$ alcohol for 2 hours and then in $1 \%$ methylene blue solution for 15 minute and in $50 \%$ and $70 \%$ alcohol for 1 hour respectively, to obtain better vision. Macroscopic characteristics were observed.

All photographs were taken with Pentax K100d digital camera. Nomina Anatomica Avium (1993) was referred for terminology (1).

\section{Results}

Macroscopic properties of syrinx were examined in sea gulls. It was observed that syrinx in sea gulls was tracheobronchial type and composed of tracheosyringeal and bronchosyringeal cartilages. Tracheosyringeal cartilages were formed from five rings. Dorsally merged five tracheosyringeal cartilage which situated at cranial side of syrinx, were shaped tympanum. Pessulus was placed caudo-medial side of tympanum. It was triangular shaped and ossified structure. It was defined that bronchosyringeal cartilage consists of 7 (both sides) ' $\mathrm{C}$ ' shaped cartilage rings. $1^{\text {st }}$ bronchosyringeal cartilage was observed thick and clear. Tracheolateral muscle (TL), one of the extrinsic muscles of syrinx, was originated from larynx and located at both sides of the trachea then it was attached to the $1^{\text {st }}$ bronchosyringeal cartilage. Lateral tympaniform membrane (MTL) was located between $1^{\text {st }}$ and $2^{\text {nd }}$ bronchosyringeal cartilage (Figure 1). Medial tympaniform membrane (MTM) was covered the open parts of $\mathrm{C}$ shaped bronchosyringeal cartilage at its medial side (Figure 2). Interbronchial ligament which connects the left and right primary bronchi was occured at the end of the medial tympaniform membrane. Foramen interbronchiale was stated between MTL, pessulus and interbronchial ligament. Bronchial cartilages were observed between bronchosyringeal cartilage and lungs as ' $\mathrm{C}$ ' shaped and 18 to 20 pairs with their medial walls were covered with membranes. Tracheolateral muscle and sternotracheal muscle which are the extrinsic muscles of syrinx were defined.

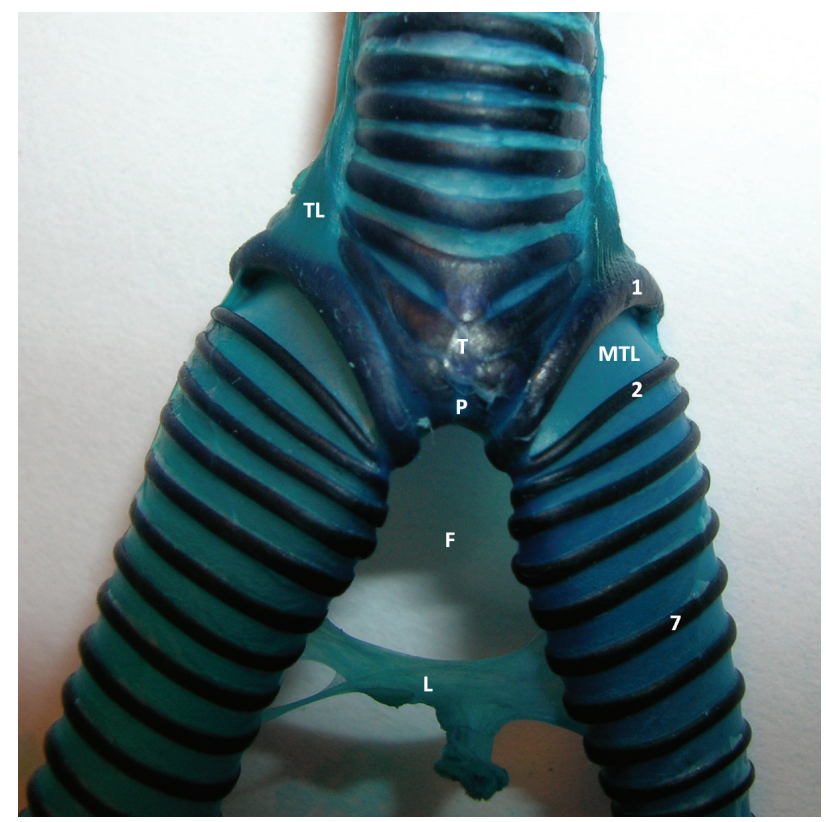

Figure 1. Ventral view of syrinx.

P: Pessulus. T: Tympanum. MTL: Lateral tympaniform membrane L: Interbronchial ligament F: Interbronchial foramen. TL: Tracheolateral muscle. $1: 1^{\text {st }}$ bronchosyringeal cartilage. $2: 2^{\text {nd }}$ bronchosyringeal cartilage. $7: 7^{\text {th }}$ bronchosyringeal cartilage. Şekil 1. Syrinx'in ventral'den görünüşü

P: Pessulus. T: Tympanum. MTL: Membrana tympaniformis lateralis L: Ligamentum interbronchiale. F: Foramen interbronchiale. TL: Musculus tracheolateralis 1: 1. cartilago bronchosyringealis. 2: 2. cartilago bronchosyringealis. 7: 7 . cartilago bronchosyringealis.

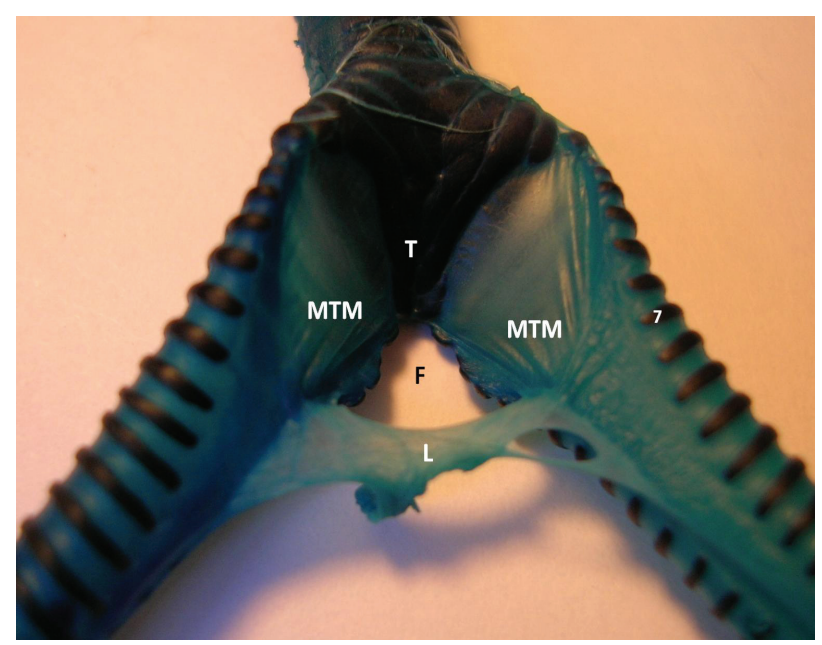

Figure 2. Dorsal view of syrinx.

MTM: Medial tympaniform membrane. F: Interbronchial foramen. L: Interbronchial ligament. T: Tympanum. 7: $7^{\text {th }}$ bronchosyringeal cartilage

Şekil 2. Syrinx'in dorsal'den görünüşü.

MTM: Membrana tympaniformis medialis F: Foramen interbronchiale. L: Ligamentum interbronchiale. T: Tympanum. 7: 7. cartilago bronchosyringealis 


\section{Discussion and conclusion}

There are lots of studies and investigations in the literature about syrinx due to the distinguishing features of singing and bird sounds among the most of the bird species. The aim of our study is to determine the morphological characteristics of syrinx in the gull species, because there is no available data for the gulls about the syrinx.

It has been determined that the gull syrinx is in tracheobronchial type as in the quail (3), the ostrich (16), the long legged buzzard (10), the roller pigeon (17), the mallard (5), the Denizli rooster (15) and the domestic fowl species (6). But, on the contrary, it has also been found that the tympanum is formed completely by tracheosyringeal cartilage in the gull species.

Tympanum has five rings in the gulls, on the other hand, it has 3-4 in the domestic fowls (6) and in the Denizli roosters (15), 3 in the ostrichs (16) and in the long-legged buzzards (10), 2 in the Japanese quails (3) and 5 in the roller pigeons (17), respectively.

Taşbaş (1994) had revealed that the tracheolateral muscle is connected to the tympanum in the Denizli roosters while Kabak et al. (2007) had found that it is connected to the first bronchosyringeal cartilage in the long legged buzzards (10). It has also been shown that this muscle has a connection similar to the long legged buzzards in the gulls.

It has been stated that bronchosyringeal cartilages have 3 half-rings in the domestic fowl and the songbirds $(3,6,11,15)$. King et al (1984) had notified that, this number is 5 or 6 in the gulls. We found that bronchosyringeal cartilage has 7 half-rings in the gulls in our study.

It is suggested in the literature that the lateral tympaniform membrane (MTL) is between the tympanum and the first bronchosyringeal cartilage $(1,3,6,13,15$, 16). Kabak et al. (2007) had found that this membrane is between the first and the second bronchosyringeal cartilages in the long legged buzzards (10). We found that the location of the membrane is the same with the long legged buzzards in the gulls.

\section{References}

1. Baumel JJ, King SA, Breasile JE, Evans HE, Berge JCV (1993): Handbook of Avian Anatomy (Nomina Anatomica Avium). Publications of the Nuttall Ornithological Club. Cambridge.

2. Çalışlar T (1977): Tavuk Diseksiyonu. Ankara Üniv Basımevi. Ankara.
3. Çevik Demirkan A, Hazıroğlu RM, Kürtül I (2007): Gross morphological and histological features of larynx, trachea and syrinx in japanese quail. Anat Histol Embriyol, 36, 215-219.

4. Demirsoy A (1992): Yaşamın Temel Kuralları. Omurgalılar/Amniyota (Sürüngenler, Kuşlar ve Memeliler). Meteksan Publisher, Ankara.

5. Frank T, König HE, Walter I (2007): The syrinx of the male mallard (Anas platyrhynchos): Special anatomical features. Anat Histol Embriyol, 36, 121-126.

6. Getty R (1975): Sisson and Grossman's the Anatomy of the Domestic Animals, Vol: 2, WB Saunders Company, London, UK.

7. Gill BF (1989): Ornithology. W.H. Freeman and Company, New York, USA.

8. Goller F, Larsen ON (1997): In situ biomechanics of the syrinx and sound generation in pigeons. J Exp Biol, 200, 2165-2176.

9. Heard DJ (1997): Avian respiratory and physiology. Seminars in Avian and exotic pet medicine, 6, 172-179.

10. Kabak M, Orhan IO, Hazıroğlu RM (2007): The gross anatomy of larynx, trachea and syrinx in the long-legged buzzard (Buteo rufinus). Anat Histol Embryol, 36, 27-32.

11. King AS, Mclelland J (1984): Birds: Their Structure And Function. Bailliere Tindall, London.

12. Kiziroğlu I (1989): Türkiye Kuşları. Orman Genel Müdürlüğü Eğitim Dairesi Başkanlığı Yayın ve Tanıtma Şube Müdürlüğü Basımı, Ankara.

13. Nickel R, Schummer A, Seiferle E (1977): Anatomy of the Domestic Birds. Verlag Paul Parey, Berlin, Germany.

14. Ocal K, Erden H (2002): Solunum sistemi. 91-96. In: N Dursun (Ed), Evcil kuşların anatomisi. Medisan Publishers, Ankara.

15. Taşbaş M, Hazıroğlu RM, Çakır A, Özer M (1994): Denizli horozunun solunum sisteminin morfolojisi. II.Larynx, trachea, syrinx. Ankara Üniv Vet Fak Derg, 41,135-153.

16. Yıldız H, Bahadır A, Akkoç A (2003): A study on the morphological structure of syrinx in ostriches (Struthio camelus). Anat Histol Embryol, 32, 187-191.

17. Yıldız H, Yılmaz B, Arıcan I (2005): Morphological structure of the syrinx in the Bursa roller pigeon (Columba Livia). Bull Vet Inst Pulawy, 49, 323-327.

Geliş tarihi: 01.07.2010 / Kabul tarihi: 24.03.2011

Adress for correspondance:

Dr. Nazan Gezer Ince

Istanbul Üniversitesi

Veteriner Fakültesi Anatomi Anabilim Dalı

Avcllar/Istanbul

e-mail:nazan@istanbul.edu.tr 